\title{
Active testing of groups at increased risk of acquiring SARS-CoV-2 in Canada: costs and human resource needs
}

\author{
Jonathon R. Campbell PhD, Aashna Uppal MScPH, Olivia Oxlade PhD, Federica Fregonese MD PhD, \\ Mayara Lisboa Bastos MD Msc, Zhiyi Lan MSc, Stephanie Law PhD, Chi Eun Oh MD MMSc, W. Alton Russell MS, \\ Giorgia Sulis MD, Nicholas Winters MSc, Mercedes Yanes-Lane MD MScPH, Marc Brisson PhD, Sonia Laszlo PhD, \\ Timothy G. Evans MD PhD, Dick Menzies MD MSc
}

Cite as: CMAJ 2020 October 5;192:E1146-55. doi: 10.1503/cmaj.201128; early-released September 9, 2020

See related editorial at www.cmaj.ca/lookup/doi/10.1503/cmaj.202120

\section{ABSTRACT \\ BACKGROUND: Testing for severe acute respiratory syndrome coronavirus 2 (SARS-CoV-2) is largely passive, which impedes epidemic control. We defined active testing strategies for SARS-CoV-2 using reverse transcription polymerase chain reaction (RT-PCR) for groups at increased risk of acquiring SARS-CoV-2 in all Canadian provinces.}

METHODS: We identified 5 groups who should be prioritized for active RT-PCR testing: contacts of people who are positive for SARS-CoV-2, and 4 at-risk populations - hospital employees, community health care workers and people in long-term care facilities, essential business employees, and schoolchildren and staff. We estimated costs, human resources and laboratory capacity required to test people in each group or to perform surveillance testing in random samples.

RESULTS: During July 8-17, 2020, across all provinces in Canada, an average of 41751 RT-PCR tests were performed daily; we estimated this required 5122 personnel and cost $\$ 2.4$ million per day (\$67.8 million per month). Systematic contact tracing and testing would increase personnel needs 1.2-fold and monthly costs to $\$ 78.9$ million. Conducted over a month, testing all hospital employees would require 1823 additional personnel, costing \$29.0 million; testing all community health care workers and persons in long-term care facilities would require 11074 additional personnel and cost $\$ 124.8$ million; and testing all essential employees would cost \$321.7 million, requiring 25965 added personnel. Testing the larger population within schools over 6 weeks would require 46368 added personnel and cost $\$ 816.0$ million. Interventions addressing inefficiencies, including saliva-based sampling and pooling samples, could reduce costs by $40 \%$ and personnel by $20 \%$. Surveillance testing in population samples other than contacts would cost $5 \%$ of the cost of a universal approach to testing at-risk populations.

INTERPRETATION: Active testing of groups at increased risk of acquiring SARS-CoV-2 appears feasible and would support the safe reopening of the economy and schools more broadly. This strategy also appears affordable compared with the $\$ 169.2$ billion committed by the federal government as a response to the pandemic as of June 2020.
T o suppress the spread of severe acute respiratory syndrome coronavirus 2 (SARS-CoV-2), the pathogen responsible for coronavirus disease 2019 (COVID-19), many countries have adopted social-isolation measures. ${ }^{1,2}$ These efforts have been largely successful but have had major economic implications. As of June 2020, the Canadian federal fiscal response alone was an estimated $\$ 169.2$ billion. ${ }^{3}$ Further, unemployment in June 2020 was $12 \%{ }^{4}$ and real gross domestic product is projected to fall $8.4 \%$ in $2020 .{ }^{5}$ These consequences have led to demands to reopen the economy quickly. ${ }^{6,7}$
Reverse transcription polymerase chain reaction (RT-PCR) is primarily used to detect acute SARS-CoV-2. ${ }^{8}$ Because of capacity constraints, RT-PCR testing was initially reserved for individuals presenting with symptoms consistent with COVID-19. ${ }^{9-11}$ As capacity expanded and the initial wave of the epidemic was brought under control, however, testing was subsequently made available to people with minimal or no symptoms. ${ }^{12}$ Modelling studies have estimated such individuals account for more than $50 \%$ of community transmission. ${ }^{13-16}$ This is supported by studies that indicate viral shedding begins before symptom onset ${ }^{17,18}$ and case series 
that document substantial transmission from asymptomatic people. ${ }^{19-22}$ Thus, testing of people with minimal or no symptoms appears to be an essential part of a comprehensive strategy to reopen the economy without creating epidemic recrudescence. ${ }^{16}$

Yet, the approach to testing has largely been passive, ${ }^{23,24}$ placing the onus to be tested on the individual. People at increased risk of acquiring SARS-CoV-2 are unlikely to seek testing unless symptoms develop. An active strategy, in which all members of selected groups at increased risk of acquiring SARS-CoV-2 are tested, would act to identify people with infection but minimal or no symptoms. This would detect individuals who might otherwise contribute to transmission and provide important epidemiologic information on how SARS-CoV-2 is affecting these populations. Testing all members of workplaces and schools would support them in safely remaining open.

We aimed to estimate costs, human resources and laboratory capacity required for active testing strategies to detect SARS-CoV-2 using RT-PCR in groups at increased risk of infection in Canada.

\section{Methods}

\section{Groups for active testing}

We conceptualized 5 groups who should be prioritized for active testing strategies based on expected prevalence of infection with SARS-CoV-2 (Appendix 1, Figure e1, available at www.cmaj.ca/ lookup/doi/10.1503/cmaj.201128/tab-related-content). The first group consisted of household and nonhousehold contacts of people who were newly diagnosed with SARS-CoV-2 infection (strategy 1 ), who would be systematically traced and tested to reach an average of 2 household and 14 nonhousehold contacts. ${ }^{25,26}$ The remaining 4 groups comprised "at-risk populations." These included all employees of acute care hospitals (strategy 2); all community health care workers, and employees and residents of long-term care facilities (strategy 3); all non-health care employees of essential businesses with major interpersonal or public contact (strategy 4); and all students and employees in primary and secondary schools (strategy 5). For each group, we estimated costs, human resource needs and laboratory capacity associated with implementing active testing strategies that were additional to the status quo. We defined the status quo based on the testing performed between July 8 and 17, 2020, which includes testing of symptomatic people and limited testing of asymptomatic people (e.g., some individuals with exposure or at high risk of exposure).

\section{Epidemiologic, testing and population parameters}

We collected SARS-CoV-2 epidemiologic and testing information and estimated the size of the groups to be tested in all Canadian provinces (as of July 17, 2020, no active cases of COVID-19 existed in Canada's territories, so they were not considered) (Appendix 1, Table e1).

As of July 17, 2020, there were 488 SARS-CoV-2 testing sites; the estimated RT-PCR laboratory capacity was 80750 tests per day. Over the period of July $8-17,2020,417508$ tests for SARS-CoV-2 were performed and 3501 (0.84\%) were positive ${ }^{27}$ (Appendix 1, Table e2).

Data from Statistics Canada provided the number of acute care hospitals and long-term care facilities, ${ }^{28,29}$ the number of employees for each in June 2020,, 30 and the number of residents of long-term care facilities. ${ }^{31,32}$ Without an estimate of the number of community health care workers in Canada, ${ }^{33}$ we used American data ${ }^{34-36}$ and assumed the number employed in Canada was proportional to population. Census data from 2016 estimated the number of people employed under each national occupation code, ${ }^{37}$ which were adjusted to June 2020 labour force size. ${ }^{4}$ Three authors (J.R.C., N.W., S.L.) independently classified occupations as essential using Quebec's stringent definition from March 2020..$^{38}$ Using a published algorithm, ${ }^{39}$ validated with $\mathrm{O}^{\star} \mathrm{Net},{ }^{40}$ we classified essential occupations as those not able to be performed at home. We then classified each of these occupations as being at high risk of interpersonal or public contact (Appendix 1, Table e3). Statistics Canada data ${ }^{41}$ and provincial reports provided estimates of the number of primary and secondary schools and number of students and employees. Additional detail is shown in Appendix 1, Table e4.

\section{Strategies for testing: costs and human resource requirements}

To inform implementation of active testing strategies, we developed a conceptual framework for testing that consisted of 6 stages, which was used for each of the 5 groups: 1 ) scheduling, 2) sampling, 3) test transport, 4) laboratory RT-PCR analysis, 5) communication of results and 6) acting on results (e.g., contact tracing). Through discussion with public health officials and laboratory managers in Quebec, we estimated human resource requirements for each stage of each strategy. Full details of how each strategy would be conducted are shown in Appendix 1. In brief, we estimated the number of health care professionals, clerical and laboratory personnel required per day ( $1 \mathrm{~d}$ was $8 \mathrm{~h}$; we considered part-time staff) for each strategy. We assumed sampling could be done at existing sampling centres by nurses or onsite by mobile teams. Mobile teams would visit health care facilities with $\geq 5$ employees, essential businesses with $\geq 20$ employees, and all schools; all others (including contacts) would be referred to existing sampling centres. We employed a microcosting approach for all recurrent costs (2020 Canadian dollars), using a health system perspective. These included costs of materials (e.g., personal protective equipment [PPE], nasopharyngeal swabs, reagents), personnel and transportation. We obtained costs from nationally representative sources. We did not include capital costs of scaling capacity (e.g., equipment, training) or existing infrastructure.

\section{Analysis of universal testing}

We estimated costs, human resources and laboratory capacity required to perform testing for each strategy, assuming $100 \%$ of each target population was tested. We calculated estimates for each province individually and summed them. We posited that systematic tracing and testing of contacts would remain a priority - as it is with other infectious diseases ${ }^{42}$ - so we assumed this would continue. Therefore, we report the monthly cost associated with systematic tracing and testing contacts. For at-risk populations, testing may occur once or repeatedly, depending on prevalence and infection risk. Therefore, we report cost, human resource and laboratory capacity estimates for 1 complete round of testing over time intervals we considered feasible; we also report estimates if testing of atrisk populations was conducted while systematic tracing and testing 
of contacts were continued. We assumed 1 complete round of testing would take 28 days for hospitals, community health care workers, long-term care facilities and essential businesses, and 42 days for the larger population in schools.

We separately calculated downstream costs of repeat testing and contact tracing and testing for each strategy. For the strategy of systematic tracing and testing of contacts, we estimated costs associated with 1 repeat test for contacts testing negative and 2 repeat tests for contacts testing positive. For strategies involving at-risk populations, we estimated costs of 2 repeat tests for each person testing positive, and the cost of tracing and providing the initial test to 16 contacts for each person testing positive.

\section{Analysis of surveillance and repeated testing}

Depending on epidemic stage and population prevalence, testing all people in at-risk populations may not be necessary, and surveillance-based testing - in which random samples of the population are tested - may be preferable. We estimated costs, human resources and laboratory capacity required to perform surveillance testing over 14 days in at-risk populations. We calculated the sample size needed for each group to estimate prevalence of SARS-CoV-2 infection using the estimated prevalence on July 17, 2020, (Appendix 1, Table e5) and if the prevalence were 10 times higher (Appendix 1, Table e6). We estimated sample sizes at the $95 \%$ confidence level, adjusting for finite sample size, ${ }^{43}$ and assuming the cluster size was $10 \%$ of individuals from each school or facility. Further detail is shown in Appendix 1.

To inform when to repeat testing of at-risk populations, we estimated the time to a new SARS-CoV-2 infection based on group size and daily risk of infection. We evaluated group sizes of 10 to 1000 with daily risks of infection of 1 per 100000 to 1 per 100 (assuming a communicability period of 10 days; ${ }^{44}$ these daily risks approximate population prevalence estimates of $0.01 \%$ to $10 \%$, respectively). Using a binomial distribution with these parameters, we ran 1000 simulations in $\mathrm{R}$ (version 3.6.3) over a 2-year period. From these simulations, we calculated the 10th, 25th and 50th percentile of the time to first infection (see Appendix 1 for code).

\section{Sensitivity analyses}

We first performed sensitivity analyses for universal testing, exploring methods to reduce costs and inefficiencies: saliva sampling instead of nasopharyngeal sampling (approximately 90\% comparative sensitivity, ${ }^{45-50}$ sampling time halved); saline rather than specific viral transport media (no loss in sensitivity ${ }^{51}$ ); heat extraction instead of reagent-based extraction (approximately 91\% comparative sensitivity ${ }^{52-54}$ ); and pooling of 4 samples for RTPCR (no loss in sensitivity ${ }^{55,56}$ ) (Appendix 1, Table e6). We also performed other sensitivity analyses for universal testing. We performed 1-way sensitivity analysis for costs, human resource inputs and estimated number of contacts for strategies 1 and 4 . As these 2 strategies represent different organizational models for sampling (contacts are tested at clinic-based facilities, while workers will be tested at their worksites), the results are shown with tornado diagrams. We examined changes in costs and human resource needs if testing uptake (consent) was $90 \%, 80 \%$ or $60 \%$. We estimated additional costs and human resource needs if whole-blood sampling for serologic testing with an enzyme-linked immunosorbent assay was done concurrently with sampling for RT-PCR. To see how sensitive estimates were to prevalence of SARS-CoV-2 infection, we multiplied our estimated prevalence by 2 and by 10 and recalculated costs and human resource needs.

\section{Ethics approval}

Ethics approval was not required for this study.

\section{Results}

\section{Analysis of universal testing}

Costs, human resources and laboratory capacity for each strategy implemented across Canada are shown in Table 1 and Table 2, and for each province in Appendix 1 (Table e8).

The status quo testing approach from July 8 to 17, $2020-$ 41751 tests per day across 488 sampling centres - cost an estimated \$2.4 million per day (\$67.8 million per month), and required 755 nurses, 213 nursing assistants, 172 other health care professionals, 3261 clerical and nonclinical staff, and 721 laboratory staff (5122 personnel total). Changes in laboratory capacity and human resource needs with each strategy are shown in Figure 1.

\section{Strategy 1: systematic tracing and testing of contacts}

As shown in Table 1 and Table 2, systematic contact tracing and testing in addition to the status quo required 47353 tests per day. All provinces had sufficient laboratory capacity (Appendix 1, Table e8). Clerical staff needs increased 1.2-fold to 3920 persons, and total monthly costs were $\$ 78.9$ million (i.e., an additional $\$ 11.1$ million per month over the status quo). The number of repeat tests required for positive individuals and negative contacts in this strategy was 180840 per month, which would cost an extra $\$ 9.9$ million.

\section{Strategies 2 to 5 : testing of at-risk populations}

Table 1 and Table 2 detail human resource needs, laboratory capacity and costs of testing all members of at-risk populations on a single occasion. Testing of all hospital employees over a month required an additional 439 health care professionals, 890 clerical staff and 494 laboratory staff to sample 27146 employees per day; the total cost was $\$ 29.0$ million. For community health care workers and long-term care facilities, to test this population over a month, 4977 health care professionals and 5484 clerical staff would be needed to sample 35620 people per day, with a total cost of $\$ 124.8$ million. Testing all 2568496 essential employees with major interpersonal or public contact over a month would require 11550 health care professionals and 12837 clerical staff and cost $\$ 321.7$ million. Finally, testing all 6012144 students and employees in primary and secondary schools over 1.5 months would require an added 20956 health care professionals, 22950 clerical staff and 2462 laboratory staff, costing $\$ 816.0$ million. Costs, human resources and laboratory capacity required when conducting testing of at-risk populations with systematic contact tracing and testing are shown in Table 1 and Table 2. 


\begin{tabular}{|c|c|c|c|c|c|c|}
\hline \multirow[b]{2}{*}{ Outcome category } & \multirow[b]{2}{*}{$\begin{array}{c}\text { Status quo: } \\
\text { current } \\
\text { strategy* }\end{array}$} & \multirow[b]{2}{*}{$\begin{array}{l}\text { Strategy 1: } \\
\text { systematically } \\
\text { trace and test } \\
\text { contacts (in } \\
\text { addition to } \\
\text { status quo) }\end{array}$} & \multicolumn{4}{|c|}{ At-risk populations } \\
\hline & & & $\begin{array}{l}\text { Strategy 2: } \\
\text { test all } \\
\text { employees } \\
\text { of acute } \\
\text { care } \\
\text { hospitals }\end{array}$ & $\begin{array}{c}\text { Strategy 3: } \\
\text { test all CHW } \\
\text { and employees } \\
\text { and residents } \\
\text { of long-term } \\
\text { care facilities }\end{array}$ & $\begin{array}{c}\text { Strategy 4: } \\
\text { test all essential } \\
\text { employees with } \\
\text { major public or } \\
\text { interpersonal } \\
\text { contact }\end{array}$ & $\begin{array}{c}\text { Strategy 5: } \\
\text { test all } \\
\text { children } \\
\text { and staff } \\
\text { of schools }\end{array}$ \\
\hline $\begin{array}{l}\text { Duration of human resource and capacity } \\
\text { needed, } d\end{array}$ & Continuous & Continuous & 28 & 28 & 28 & 42 \\
\hline No. of people sampled per day & 41751 & 47353 & 27146 & 35620 & 91732 & 143146 \\
\hline \multicolumn{7}{|l|}{ Primary analysis } \\
\hline \multicolumn{7}{|l|}{ Human resource requirements $\dagger$} \\
\hline No. of health care professionals $\ddagger$ & 1140 & 1385 & 439 & 4977 & 11550 & 20956 \\
\hline No. of clerical staff§ & 3261 & 3920 & 890 & 5484 & 12837 & 22950 \\
\hline No. of laboratory staff & 721 & 818 & 494 & 613 & 1578 & 2462 \\
\hline $\begin{array}{l}\text { No. of total personnel if including } \\
\text { Strategy } 1\end{array}$ & - & - & 7946 & 17197 & 32088 & 52491 \\
\hline \multicolumn{7}{|l|}{ Laboratory capacity requirements } \\
\hline No. of laboratory tests run per day & 41751 & 47353 & 27146 & 35620 & 91732 & 143146 \\
\hline $\begin{array}{l}\text { No. of laboratory tests run per day } \\
\text { including Strategy } 1\end{array}$ & - & - & 74499 & 82972 & 139085 & 190499 \\
\hline \multicolumn{7}{|l|}{ Sensitivity analysesฯ } \\
\hline \multicolumn{7}{|l|}{ Saliva sampling** } \\
\hline \multicolumn{7}{|l|}{ Human resource requirements $\uparrow$} \\
\hline Change in no. of health care professionals $\ddagger$ & - & - & -194 & -921 & -2150 & -4090 \\
\hline Change in no. of clerical staff§ & - & - & -65 & -921 & -2150 & -4090 \\
\hline \multicolumn{7}{|l|}{ Pooling samples 4:1 } \\
\hline \multicolumn{7}{|l|}{ Human resource requirements $\dagger$} \\
\hline Change in no. of clerical staff & +13 & +19 & +3 & +3 & +3 & +2 \\
\hline Change in no. of laboratory staff & -473 & -525 & -322 & -423 & -1100 & -1718 \\
\hline \multicolumn{7}{|l|}{ Laboratory capacity requirements } \\
\hline Change in no. of laboratory tests run per day & -29880 & -33465 & -19972 & -26216 & -67878 & -105928 \\
\hline $\begin{array}{l}\text { Change in no. of laboratory tests run } \\
\text { per day including strategy } 1\end{array}$ & - & - & -53437 & -59680 & -101342 & -139393 \\
\hline \multicolumn{7}{|l|}{ All analyses togethert† } \\
\hline \multicolumn{7}{|l|}{ Human resource requirements $\dagger$} \\
\hline Change in no. of health care professionals $\ddagger$ & - & - & -194 & -921 & -2150 & -4090 \\
\hline Change in no. of clerical staff & +13 & +19 & -62 & -918 & -2147 & -4088 \\
\hline Change in no. of laboratory staff & -473 & -525 & -322 & -423 & -1100 & -1718 \\
\hline \multicolumn{7}{|l|}{ Laboratory capacity requirements } \\
\hline Change in no. of laboratory tests run per day & -29880 & -33465 & -19972 & -26216 & -67878 & -105928 \\
\hline $\begin{array}{l}\text { Change in no. of laboratory tests run } \\
\text { per day including strategy } 1\end{array}$ & - & - & -53437 & -59680 & -101342 & -139393 \\
\hline \multicolumn{7}{|c|}{ 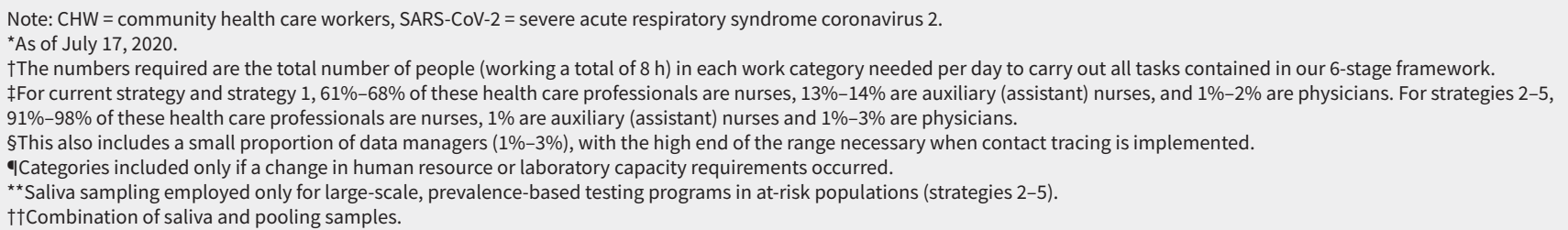 } \\
\hline
\end{tabular}


Table 2: Costs for conducting active testing strategies for SARS-CoU-2 across Canada

\begin{tabular}{|c|c|c|c|c|c|c|}
\hline \multirow[b]{2}{*}{ Outcome category } & \multirow[b]{2}{*}{$\begin{array}{l}\text { Status quo: } \\
\text { current } \\
\text { strategy }\end{array}$} & \multirow[b]{2}{*}{$\begin{array}{l}\text { Strategy 1: } \\
\text { systematically } \\
\text { trace and test } \\
\text { contacts (in } \\
\text { addition to } \\
\text { status quo) }\end{array}$} & \\
\hline & & & $\begin{array}{l}\text { Strategy 2: } \\
\text { test all } \\
\text { employees of } \\
\text { acute care } \\
\text { hospitals }\end{array}$ & $\begin{array}{l}\text { Strategy 3: } \\
\text { test all CHW } \\
\text { and } \\
\text { employees } \\
\text { and residents } \\
\text { of long-term } \\
\text { care facilities }\end{array}$ & $\begin{array}{l}\text { Strategy 4: } \\
\text { test all } \\
\text { essential } \\
\text { employees } \\
\text { with public or } \\
\text { interpersonal } \\
\text { contact }\end{array}$ & $\begin{array}{l}\text { Strategy 5: } \\
\text { test all } \\
\text { children and } \\
\text { staff of } \\
\text { schools }\end{array}$ \\
\hline $\begin{array}{l}\text { Time frame for cost } \\
\text { calculation, } d\end{array}$ & 28 & 28 & 28 & 28 & 28 & 42 \\
\hline No. of people sampled per day & 41751 & 47353 & 27146 & 35620 & 91732 & 143146 \\
\hline $\begin{array}{l}\text { No. of people to sample over } \\
\text { time frame }\end{array}$ & 1169028 & 1325872 & 760095 & 997350 & 2568496 & 6012144 \\
\hline \multicolumn{7}{|l|}{ Primary analysis } \\
\hline \multicolumn{7}{|l|}{ Costs, $\$$} \\
\hline Per 100 persons tested & 5800 & 5950 & 3820 & 12520 & 12520 & 13570 \\
\hline Per day & 2.4 million & 2.8 million & 1.0 million & 4.5 million & 11.5 million & 19.4 million \\
\hline Total over time frame & 67.8 million & 78.9 million & 29.0 million & 124.8 million & 321.7 million & 816.0 million \\
\hline Total cost including strategy 1 & - & - & 107.9 million & 203.7 million & 400.6 million & 934.3 million \\
\hline \multicolumn{7}{|l|}{ Additional considerations } \\
\hline $\begin{array}{l}\text { No. of additional tests for } \\
\text { contacts or repeat testing over } \\
\text { time frame } \dagger\end{array}$ & 19605 & 180840 & 33790 & 43350 & 43950 & 52600 \\
\hline Total cost of additional tests, $\$$ & 1.2 million & 9.9 million & 2.1 million & 2.8 million & 2.8 million & 3.3 million \\
\hline \multicolumn{7}{|l|}{ Sensitivity analyses $¥$} \\
\hline \multicolumn{7}{|l|}{ Saliva sampling§ } \\
\hline Cost savings over time frame & - & - & -5.3 million & -39.6 million & -91.4 million & -257.6 million \\
\hline \multicolumn{7}{|l|}{ Saline transport media } \\
\hline Cost savings over time frame & -3.9 million & -4.4 million & -2.5 million & -3.3 million & -8.5 million & -20.0 million \\
\hline $\begin{array}{l}\text { Cost savings if implemented } \\
\text { with strategy } 1\end{array}$ & - & - & -6.9 million & -7.7 million & -12.9 million & -26.6 million \\
\hline \multicolumn{7}{|l|}{ Heat extraction } \\
\hline Cost savings over time frame & -12.3 million & -14.0 million & -8.0 million & -10.5 million & -27.1 million & -63.5 million \\
\hline $\begin{array}{l}\text { Cost savings if implemented } \\
\text { with strategy } 1\end{array}$ & - & - & -22.0 million & -24.5 million & -41.1 million & -84.5 million \\
\hline \multicolumn{7}{|l|}{ Pooling samples 4:1 } \\
\hline Cost savings over time frame & -15.5 million & -17.3 million & -10.4 million & -13.6 million & -35.4 million & -83.1 million \\
\hline $\begin{array}{l}\text { Cost savings if implemented } \\
\text { with strategy } 1\end{array}$ & - & - & -27.7 million & -31.0 million & -52.8 million & -109.1 million \\
\hline \multicolumn{7}{|l|}{ All analyses togetherq } \\
\hline Cost savings over time frame & -22.9 million & -25.8 million & -17.7 million & -56.3 million & -135.2 million & -356.8 million \\
\hline $\begin{array}{l}\text { Cost savings if implemented } \\
\text { with strategy } 1\end{array}$ & - & - & -43.6 million & -82.1 million & -161.1 million & -395.5 million \\
\hline 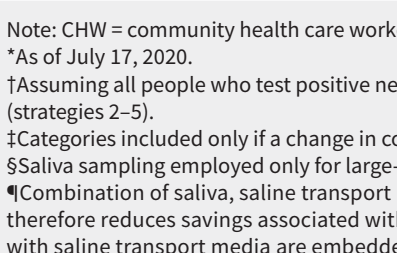 & $\begin{array}{l}\text { SARS-CoV-2 = sev } \\
2 \text { additional tests } \\
\text { occurred. } \\
\text { le, prevalence-bas } \\
\text { dia, heat extractio }\end{array}$ & $\begin{array}{l}\text { ute respiratory } \\
\text { ategies), all neg }\end{array}$ & $\begin{array}{l}\text { coronavirus } 2 \text {. } \\
\text { acts need } 1 \text { addit }\end{array}$ & $\begin{array}{l}-5) \text {. } \\
\text { for } 2 \text { reasons: ( }\end{array}$ & samples re & $\begin{array}{l}\text { gent use and } \\
\text { gs associated }\end{array}$ \\
\hline
\end{tabular}




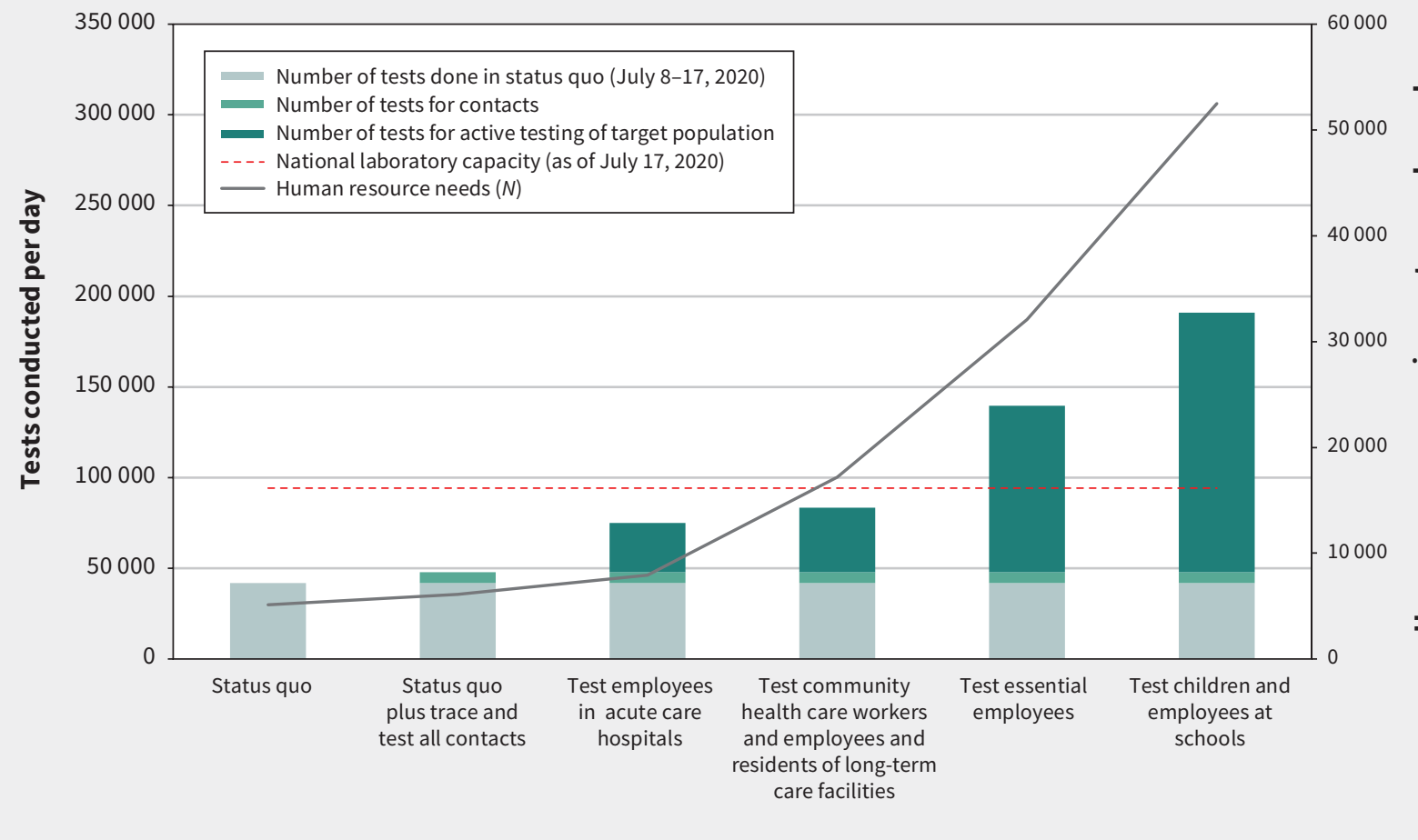

Figure 1: Changing laboratory capacity requirements across strategies, with attendant changes in total human resources (health care professionals, clerical staff and laboratory staff). Note: Total number of personnel required, and laboratory capacity needed for each strategy. The estimated national laboratory capacity (as of July 17, 2020) is denoted with the dashed line. For at-risk populations, incremental laboratory capacity needs are shown, assuming systematic tracing and testing of contacts is implemented and continued; total personnel are shown for these same at-risk populations assuming systematic tracing and testing of contacts is implemented and continued.

\section{Analysis of surveillance and repeated testing}

Cost and human resource estimates for surveillance testing in randomly selected samples of at-risk populations are shown in Table 3. Costs were estimated to be about $5 \%$ those of universal testing of at-risk groups. Estimated costs for each round of surveillance testing were $\$ 2.3$ million for hospital employees, $\$ 6.6$ million for community health care workers and employees and residents of longterm care facilities; $\$ 14.4$ million for other essential workers; and $\$ 45.6$ million within schools. Conducted individually, all provinces had laboratory capacity to conduct surveillance testing in 1 of these at-risk populations in parallel with systematic tracing and testing of contacts, but only 3 provinces had capacity to conduct surveillance testing simultaneously in all populations (Appendix 1, Table e9).

In our simulations, the critical determinant of the frequency of repeat surveillance or universal testing was the daily risk of acquiring SARS-CoV-2. If daily SARS-CoV-2 infection risk is 1 per 100000 (corresponding to a population prevalence of about $0.01 \%$ ), then population groups of 100 or fewer (e.g., smaller workforces or classes in primary or secondary schools) would be more than $90 \%$ likely to remain infection free for more than 3 months, and testing could be repeated quarterly. In contrast, if daily SARS-CoV-2 infection risk is 1 per 10000 (population prevalence of about $0.1 \%$ ), then groups of 100 or fewer would be more than $90 \%$ likely to remain infection free for about 4 weeks or more, suggesting testing should be repeated monthly. Larger groups, or higher infection risk, would require repeated testing at shorter intervals (Appendix 1, Table e10).

\section{Sensitivity analyses}

Implementing interventions to reduce costs and improve efficiency were predicted to substantially affect resources required for universal testing (Table 1, Table 2). Saliva-based sampling would reduce costs by $25 \%-30 \%$ and nursing and clerical resource needs by about $20 \%$. Conversely, heat extraction and saline transport media did not reduce resource needs as substantially. Pooling samples 4:1 could reduce reagents and laboratory technician time by nearly $70 \%$. All improvements combined reduced total costs by $40 \%$ and personnel needs by $20 \%$ for strategies involving at-risk populations. In 1-way sensitivity analysis, cost of systematically tracing and testing contacts was most sensitive to RT-PCR reagent cost, and personnel needs were most sensitive to activities related to tracing and scheduling contacts. For testing at-risk essential workers, both cost and personnel needs were most sensitive to the time required to obtain samples (Appendix 1, Figure e2). Reduced acceptance of testing resulted in parallel reductions in human resource requirements and costs (Appendix 1, Table e11). Performing serologic sampling and testing alongside RT-PCR cost an additional \$31 per person, based on an assumed manufacturers' cost of $\$ 10$ per test (Appendix 1, Table e11). Analyses considering increased prevalence of SARS-CoV-2 infection resulted in proportional increases to the number of contacts traced and tested in all strategies, but minimally affected cost and human resource needs for strategies in at-risk populations (Appendix 1, Table e12). 
Table 3: Costs, testing capacity and human resource needs for conducting SARS-CoV-2 surveillance testing across Canada over 14-day intervals

\begin{tabular}{|c|c|c|c|c|c|}
\hline Outcome category & $\begin{array}{l}\text { Employees of } \\
\text { acute care } \\
\text { hospitals }\end{array}$ & $\begin{array}{l}\text { CHW and employees } \\
\text { and residents of } \\
\text { long-term care } \\
\text { facilities }\end{array}$ & $\begin{array}{l}\text { Essential employees } \\
\text { with public or } \\
\text { interpersonal } \\
\text { contact }\end{array}$ & $\begin{array}{l}\text { Children and } \\
\text { staff of } \\
\text { schools }\end{array}$ & $\begin{array}{l}\text { All groups at } \\
\text { once }\end{array}$ \\
\hline \multicolumn{6}{|l|}{ Situation on July 17, 2020} \\
\hline $\begin{array}{l}\text { Estimated SARS-CoV- } 2 \text { prevalence in } \\
\text { population, } \%\end{array}$ & 0.25 & 0.25 & 0.1 & 0.05 & - \\
\hline Total no. of people to sample* & 60942 & 30462 & 86951 & 302313 & 408668 \\
\hline \multicolumn{6}{|l|}{ Human resource requirements } \\
\hline No. of health care professionals & 73 & 588 & 1235 & 3633 & 5529 \\
\hline No. of clerical staff & 145 & 619 & 1322 & 3933 & 6019 \\
\hline No. of laboratory staff & 79 & 37 & 107 & 371 & 595 \\
\hline \multicolumn{6}{|l|}{ Laboratory capacity requirements } \\
\hline No. of laboratory tests run per day & 4353 & 2176 & 6211 & 21594 & 34333 \\
\hline Costs to test all, $\$$ & 2.3 million & 6.6 million & 14.4 million & 45.6 million & 69.1 million \\
\hline \multicolumn{6}{|l|}{ Situation if prevalence was $10 \times$ higher } \\
\hline $\begin{array}{l}\text { Estimated SARS-CoV- } 2 \text { prevalence in } \\
\text { population, } \%\end{array}$ & 2.5 & 2.5 & 1.0 & 0.5 & - \\
\hline Total no. of people to sample $†$ & 48728 & 19391 & 56403 & 198776 & 323298 \\
\hline \multicolumn{6}{|l|}{ Human resource requirements } \\
\hline No. of health care professionals & 58 & 379 & 801 & 2404 & 3642 \\
\hline No. of clerical staff & 116 & 399 & 857 & 2601 & 3973 \\
\hline No. of laboratory staff & 63 & 24 & 69 & 244 & 401 \\
\hline \multicolumn{6}{|l|}{ Laboratory capacity requirements } \\
\hline No. of laboratory tests run per day & 3481 & 1385 & 4029 & 14198 & 23093 \\
\hline Costs to test all, $\$$ & 1.9 million & 4.3 million & 9.3 million & 30.2 million & 45.7 million \\
\hline
\end{tabular}

\section{Interpretation}

Our analysis shows that actively testing populations at increased risk of acquiring SARS-CoV-2 in Canada can be feasible. Systematic tracing and testing of 16 contacts per person given a new diagnosis of SARS-CoV-2 infection marginally increases testing costs and could be accomplished with current laboratory capacity. The cost of universal testing for at-risk populations would be $\$ 1.3$ billion for 1 round of testing. Even if repeated, these costs represent a small fraction of the $\$ 169.2$ billion in Canadian federal fiscal response to the COVID-19 pandemic (as of June 2020). Implementing interventions to reduce inefficiencies in sampling and laboratory procedures could substantially reduce these costs. Surveillance testing - for which capacity already exists - is an important and less costly approach to understanding the extent and dynamics of SARS-CoV- 2 in at-risk populations.

Our findings place into context the substantial response needed to ensure regular testing can be provided to populations who need it most. These resource and population size estimates are useful for other jurisdictions seeking to implement active testing strategies for SARS-CoV-2. In Canada, the populations targeted for active testing are large - some 4 million people in hospitals, community health care, long-term care and essential businesses, and 6 million within schools - but others have advocated for a similarly ambitious approach. ${ }^{57-59}$ In other countries, such as South Korea, ${ }^{60}$ Hong Kong ${ }^{61}$ and Germany, ${ }^{62}$ testing capacity was rapidly expanded to help control the initial epidemic wave. Innovative programs to expand testing, like the Rapid Acceleration of Diagnostics (RADx) program in the United States, ${ }^{63}$ are also under way. These examples show massive testing programs are possible when governments prioritize efforts, provide adequate funding, involve all sectors and leverage human resources.

The most important benefit of an active testing approach is the identification of people infected with SARS-CoV-2 who have minimal or no symptoms and are currently undetected. The approach to preventing transmission from such individuals during the first wave of COVID-19 in Canada was to shut down many activities. This has had major social and economic consequences. We suggest that actively testing those at increased risk 
of acquiring SARS-CoV-2 - and isolating individuals found to be infected - could be equally effective to arrest community transmission and is associated with far less social and economic cost.

There are other potential benefits to our proposed approach. These include strengthening of public health and laboratory capacity, which is essential to prevent recrudescence. Such public health capacity could also be leveraged for eventual coordination and implementation of vaccination against SARS-CoV-2. Active testing will also provide critical epidemiologic data necessary for decisions on further testing or control measures. By initiating surveillance testing immediately, evidence-based decisions on further testing entire groups could be made as capacity is built. If groups are found to have a low prevalence of SARS-CoV-2 infection, routine surveillance testing would be essential to rapidly respond to increases. Additionally, unused capacity could be diverted to testing entire groups with higher prevalence more frequently and rapidly. Gathering samples for both serologic ${ }^{64,65}$ and RT-PCR testing to detect previous and current infection could add considerably to the epidemiologic value of active testing, particularly as the epidemic continues.

Rapidly scaling human resource and laboratory capacity is critical to the success of these strategies. This may be supported by engaging medical students, ${ }^{66}$ leveraging other health care professional ${ }^{67}$ and using academic and private laboratories. ${ }^{68}$ Our sensitivity analyses also highlight other approaches that may expedite scale-up. The most notable is gathering saliva samples. This form of sampling would be more acceptable - particularly to children, a key consideration when schools reopen - and has excellent sensitivity. ${ }^{45-50}$ Saliva samples also eliminate the need for nasopharyngeal swabs, a trained health care professional to perform sampling, and the use of costly and scarce PPE.

\section{Limitations}

Much of how SARS-CoV-2 sampling and contact tracing is performed was derived from Quebec during the first wave of the pandemic, although this was validated with other settings. ${ }^{69-73}$ There is heterogeneity among provincial health systems, and the epidemiology of SARS-CoV-2 is changing rapidly. We conducted sensitivity analyses applicable to other scenarios, such as epidemic resurgence, and new approaches - such as the approval of accurate, inexpensive point-of-care tests - can be implemented with the tool we developed. ${ }^{74}$ We did not, however, estimate potential epidemiologic impacts of active testing, although we expect increased testing and contact tracing would help reduce community transmission, resulting in substantial downstream health system savings. For contacts, other studies have estimated impacts. ${ }^{75-77}$ It is possible some people in our strategies are already being tested (e.g., some contacts) and other groups that may require testing (e.g., travellers, visitors to long-term care) were not considered. We used a strict definition for essential workers. As workplaces such as bars and fitness centres reopen, and industries such as air travel see increasing customer volumes, more workers will be at increased risk of acquiring SARS-CoV-2. We did not consider costs associated with capacity building and existing infrastructure; nor did we include health system costs beyond testing, such as inpatient or outpatient medical costs, as most people detected would be unlikely to seek care or be detected otherwise.

\section{Conclusion}

As workplaces and schools reopen after the first wave of COVID19 in Canada, testing priorities and strategies are needed to prevent surges in community transmission of SARS-CoV-2. Active testing strategies can identify a high proportion of people with SARS-CoV-2 infection and minimal or no symptoms, who are currently an important source of community transmission. We believe that a strategy of actively testing large population groups who are at increased risk of acquiring SARS-CoV-2 is feasible and affordable in Canada. This testing approach should be an integral component of a broad strategy to allow all Canadians to return safely to work and school.

\section{References}

1. Hale T, Angrist N, Kira B, et al. Variation in government responses to COVID-19. BSG-WP-2020/032. Version 6.0. Oxford (UK): Blavatnik School of Government, University of Oxford; 2020. Available: www.bsg.ox.ac.uk/research/publications/ variation-government-responses-covid-19 (accessed 2020 Aug. 24).

2. Kaplan J, Frias L, McFall-Johnsen M. Our ongoing list of how countries are reopening, and which ones remain under lockdown. Business Insider 2020 Aug. 18. Available: www.businessinsider.com/countries-on-lockdown-coronavirus -italy-2020-3 (accessed 2020 Aug. 24).

3. Scenario analysis update: COVID-19 pandemic and oil price shocks. Ottawa: Office of the Parliamentary Budget Officer; 2020. Available: www.pbo-dpb. gc.ca/web/default/files/Documents/Reports/RP-2021-009-S/RP-2021-009-S_en .pdf (accessed 2020 July 23).

4. Labour Force Survey, June 2020. The Daily. Ottawa: Statistics Canada; 2020. Available: www150.statcan.gc.ca/n1/daily-quotidien/200710/dq200710a-eng. htm (accessed 2020 May 14).

5. World economic outlook update: a crisis like no other, an uncertain recovery. Washington (DC): International Monetary Fund; 2020. Available: www.imf.org/ en/Publications/WEO/Issues/2020/06/24/WEOUpdateJune2020 (accessed 2020 July 23).

6. Miller Z, Colvin J, Lemire J. Out to regain footing, Trump shifts virus focus to economy. Daily Herald 2020 Apr. 27. Available: www.dailyherald.com/news/20200427/ out-to-regain-footing-trump-shifts-virus-focus-to-economy (accessed 2020 May 14).

7. Hinkson K, Shingler B. Legault is gradually reopening Quebec. Are we ready? CBC News 2020 Apr. 22, updated 2020 Apr. 30. Available: www.cbc.ca/news/canada/ montreal/quebec-open-schools-economy-covid-19-1.5541594 (accessed 2020 May 14).

8. Sethuraman N, Jeremiah SS, Ryo A. Interpreting diagnostic tests for SARSCoV-2. JAMA 2020;323:2249-51.

9. Coronavirus COVID-19. Montréal: Santé Montréal. Available: https://santemontreal. qc.ca/en/public/coronavirus-covid-19/ (accessed 2020 May 14).

10. Overview of testing for SARS-CoV-2. Atlanta: Centers for Disease Control and Prevention; 2020. Available: www.cdc.gov/coronavirus/2019-ncov/hcp/clinical -criteria.html (accessed 2020 Aug. 24).

11. Testing in Ottawa now open to anyone with COVID-19 symptoms. CBC News 2020 May 13. Available: www.cbc.ca/news/canada/ottawa/ottawa-covid19 -test-symptoms-1.5567441 (accessed 2020 May 14)

12. Neustaeter B. Can I get tested for COVID-19? What the rules are in each province and territory. CTV News 2020 May 25. Available: www.ctvnews.ca/health/ coronavirus/can-i-get-tested-for-covid-19-what-the-rules-are-in-each-province -and-territory-1.4953618 (accessed 2020 July 23).

13. Kucharski AJ, Klepac P, Conlan AJK, et al.; CMMID COVID-19 working group. Effectiveness of isolation, testing, contact tracing, and physical distancing on reducing transmission of SARS-CoV-2 in different settings: a mathematical modelling study. Lancet Infect Dis 2020 June 15 [Epub ahead of print]. doi: 10.1016/S1473-3099(20)30457-6.

14. Li R, Pei S, Chen B, et al. Substantial undocumented infection facilitates the rapid dissemination of novel coronavirus (SARS-CoV-2). Science 2020;368:489-93.

15. Koo JR, Cook AR, Park M, et al. Interventions to mitigate early spread of SARSCoV-2 in Singapore: a modelling study. Lancet Infect Dis 2020;20:678-88.

16. Hao X, Cheng S, Wu D, et al. Reconstruction of the full transmission dynamics of COVID-19 in Wuhan. Nature 2020;584:420-4

17. Wiersinga WJ, Rhodes A, Cheng AC, et al. Pathophysiology, transmission, diagnosis, and treatment of coronavirus disease 2019 (COVID-19): a review. JAMA 2020 July 10 [Epub ahead of print]. doi: 10.1001/jama.2020.12839. 
18. He X, Lau EHY, Wu P, et al. Temporal dynamics in viral shedding and transmissibility of COVID-19. Nat Med 2020;26:672-5.

19. Bai Y, Yao L, Wei T, et al. Presumed asymptomatic carrier transmission of COVID-19. JAMA 2020;323:1406-7.

20. Li C, Ji F, Wang L, et al. Asymptomatic and human-to-human transmission of SARS-CoV-2 in a 2-family cluster, Xuzhou, China. Emerg Infect Dis 2020;26: 1626-8.

21. Ye F, Xu S, Rong Z, et al. Delivery of infection from asymptomatic carriers of COVID-19 in a familial cluster. Int J Infect Dis 2020;94:133-8.

22. Arons MM, Hatfield KM, Reddy SC, et al.; Public Health-Seattle and King County and CDC COVID-19 Investigation Team. Presymptomatic SARS-CoV-2 infections and transmission in a skilled nursing facility. N Engl J Med 2020;382:2081-90

23. Ministry of Health. COVID-19 provincial testing guidance update. Toronto: Ministry of Health and Long-Term Care; 2020. Available: www.health.gov.on.ca/en/ pro/programs/publichealth/coronavirus/docs/2019_covid_testing_guidance.pdf (accessed 2020 July 23).

24. Weeks C. Ontario's contact tracing efforts are falling short, experts say. Globe and Mail [Toronto]. Available: www.theglobeandmail.com/canada/article-ontarios -contact-tracing-efforts-are-falling-short-experts-say/ (accessed 2020 July 23).

25. Data tables, 2016 Census: structural type of dwelling (10) and household size (8) for occupied private dwellings of Canada, provinces and territories, census divisions and census subdivisions, 2016 Census - 100\% data [tables]. Ottawa: Statistics Canada; modified 2019 June 17. Available: www12.statcan.gc.ca/ census-recensement/2016/dp-pd/dt-td/Rp-eng.cfm?TABID=2\&Lang=E\&APATH $=3 \& D E T A I L=0 \& D I M=0 \& F L=A \& F R E E=0 \& G C=0 \& G I D=1159582 \& G K=0 \& G R P=1 \& P I D=$ 109536\&PRID $=10 \& P T Y P E=109445 \& S=0 \& S H O W A L L=0 \& S U B=0 \&$ Temporal $=2016 \&$ THEME $=116 \& \mathrm{VID}=0 \& \mathrm{VNAMEE}=\& \mathrm{VNAMEF}=\& \mathrm{D} 1=0 \& \mathrm{D} 2=0 \& \mathrm{D} 3=0 \& \mathrm{D} 4=0 \& \mathrm{D} 5=0 \& \mathrm{D} 6=0$ (accessed 2020 May 14).

26. Pringle J. 1,500 close contacts for positive COVID-19 cases in Ottawa: Dr. Etches. CTV News [Ottawa] 2020 Mar. 25. Available: https://ottawa.ctvnews.ca/ mobile/1-500-close-contacts-for-positive-covid-19-cases-in-ottawa-dr-etches-1 .4867734 ? cache=almppngbro?clipld=89950 (accessed 2020 May 14).

27. Coronavirus disease 2019 (COVID-19): epidemiology update. Ottawa: Public Health Agency of Canada; modified 2020 Aug. 23. Available: https://health-infobase .canada.ca/covid-19/epidemiological-summary-covid-19-cases.html\#a6 (accessed 2020 July 19)

28. Health care and social assistance: 6221 - General medical and surgical hospitals. In: Summary - Canadian Industry Statistics. Ottawa: Innovation, Science and Economic Development Canada; modified 2020 Mar. 11. Available: https://strategis. ic.gc.ca/app/scr/app/cis/summary-sommaire/6221 (accessed 2020 May 14).

29. 623 - Nursing and residential care facilities. In: Businesses - Canadian Industry Statistics. Ottawa: Innovation, Science and Economic Development Canada; modified 2020 Mar. 11. Available: https://strategis.ic.gc.ca/app/scr/app/cis/ businesses-entreprises/623 (accessed 2020 May 14).

30. Data tables, 2016 Census: Industry - North American Industry Classification System (NAICS) 2012 (427A), class of worker (5A), labour force status (3), age $(13 A)$ and sex (3) for the labour force aged 15 years and over in private households of Canada, provinces and territories, census metropolitan areas and census agglomerations, 2016 Census - 25\% sample data [tables]. Ottawa: Statistics Canada; modified 2019 June 17. Available: www12.statcan.gc.ca/ census-recensement/2016/dp-pd/dt-td/Rp-eng.cfm?LANG=E\&APATH=3\&DETAI $\mathrm{L}=0$ \&DIM $=0$ \&FL $=A \& F R E E=0 \& G C=0 \& G I D=0 \& G K=0 \& G R P=1 \& P I D=110695 \& P R I D=10$ \&PTYPE $=109445 \& S=0 \& S H O W A L L=0 \& S U B=0 \& T e m p o r a l=2017 \& T H E M E=124 \& V I D$ $=0 \& V N A M E E=\& V N A M E F=($ accessed 2020 May 14)

31. Data tables, 2016 Census: type of collective dwelling (16), age (20) and sex (3) for the population in collective dwellings of Canada, provinces and territories, 2016 Census - 100\% data. Ottawa: Statistics Canada; modified 2019 June 17. Available: www12.statcan.gc.ca/census-recensement/2016/dp-pd/dt-td/Rp-eng .cfm? LANG=E\&APATH=3\&DETAIL=0\&DIM=0\&FL=A\&FREE=0\&GC=0\&GID=0\&GK=0\& $\mathrm{GRP}=1 \& \mathrm{PID}=109537 \& \mathrm{PRID}=0 \& \mathrm{PTYPE}=109445 \& \mathrm{~S}=0 \& \mathrm{SHOWALL}=0 \& \mathrm{SUB}=0 \& \mathrm{Tem}$ poral=2016\&THEME=116\&VID=0\&VNAMEE $=\& V N A M E F=($ accessed 2020 May 14).

32. Table 17-10-0009-01: Population estimates, quarterly [table]. Ottawa: Statistics Canada; modified 2020 Aug. 24. Available: www150.statcan.gc.ca/t1/tbl1/en/ tv.action?pid=1710000901 (accessed 2020 May 14).

33. Najafizada SAM, Bourgeault IL, Labonte R, et al. Community health workers in Canada and other high-income countries: a scoping review and research gaps. Can J Public Health 2015;106:e157-64.

34. Rosenthal EL, Brownstein JN, Rush CH, et al. Community health workers: part of the solution. Health Aff (Millwood) 2010;29:1338-42.

35. Occupational employment and wages, May 19: 21-1094 - Community health workers. Washington (DC): U.S. Bureau of Labor Statistics; modified 2020 July 6. Available: www.bls.gov/oes/current/oes211094.htm (accessed 2020 July 22).
36. A summary of the National Community Health Advisor study: weaving the future. Tucson (AZ): Center for Rural Health, University of Arizona; 1998, reprinted 2000. Available: https://crh.arizona.edu/sites/default/files/pdf/publications/ CAHsummaryALL.pdf (accessed 2020 July 22).

37. Data tables, 2016 Census: occupation - National Occupational Classification (NOC) 2016 (693A), industry - North American Industry Classification System (NAICS) 2012 (23A), labour force status (3), age (5) and sex (3) for the Labour Force aged 15 years and over in private households of Canada, provinces and territories, census metropolitan areas and census agglomerations, 2016 Census - 25\% sample data. Ottawa: Statistics Canada; modified 2019 June 17. Available: www12. statcan.gc.ca/census-recensement/2016/dp-pd/dt-td/Rp-eng.cfm?TABID=2\&Lang= $E \& A P A T H=3 \& D E T A I L=0 \& D I M=0 \& F L=A \& F R E E=0 \& G C=0 \& G I D=1341679 \& G K=0 \& G R P=1$ $\& P I D=111858 \& P R I D=10 \& P T Y P E=109445 \& S=0 \& S H O W A L L=0 \& S U B=0 \&$ Temporal $=$ 2017\&THEME=124\&VID=0\&VNAMEE=\&VNAMEF=\&D1=0\&D2=0\&D3=0\&D4=0\&D5= 0\&D6=0 (accessed 2020 May 14).

38. Government of Quebec communicates the list of essential services and commer cial activities. Montréal: Stikeman Elliott; 2020. Available: www.stikeman.com/ en-ca/kh/corporations-commercial-law/Government-of-Quebec-Communicates -the-List-of-Essential-Services-and-Commercial-Activities (accessed 2020 Aug. 24).

39. Dingel JI, Neiman B. How many jobs can be done at home? Chicago: Becker Friedman Institute for Economics at UChicago; 2020. Available: https://bfi.uchicago. edu/wp-content/uploads/BFI_White-Paper_Dingel_Neiman_3.2020.pdf (accessed 2020 May 14).

40. O^NET OnLine [main page]. Available: www.onetonline.org/ (accessed 2020 May 14)

41. Table 37-10-0109-01: Number of students in elementary and secondary schools, by school type and program type. Ottawa: Statistics Canada; modified 2020 Aug. 24. Available: www150.statcan.gc.ca/t1/tbl1/en/tv.action?pid=3710010901 (accessed 2020 May 14).

42. WHO consolidated guidelines on tuberculosis: Module 1 - Prevention: tuberculosis preventive treatment [guideline]. Geneva: World Health Organization; 2020. Available: www.who.int/publications-detail-redirect/who-consolidated-guidelines-on -tuberculosis-module-1-prevention-tuberculosis-preventive-treatment (accessed 2020 July 31).

43. Fosgate GT. Practical sample size calculations for surveillance and diagnostic investigations. J Vet Diagn Invest 2009;21:3-14.

44. Coronavirus disease (COVID-19): summary of assumption. Ottawa: Public Health Agency of Canada; 2020. Available: www.canada.ca/en/public-health/services/ diseases/2019-novel-coronavirus-infection/health-professionals/assumptions. html\#a4 (accessed 2020 May 15).

45. To KK-W, Tsang OT-Y, Yip CC-Y, et al. Consistent detection of 2019 novel coronavirus in saliva. Clin Infect Dis 2020;71:841-3.

46. Azzi L, Carcano G, Gianfagna F, et al. Saliva is a reliable tool to detect SARSCoV-2. J Infect 2020;81:e45-50.

47. Williams E, Bond K, Zhang B, et al. Saliva as a non-invasive specimen for detection of SARS-CoV-2. J Clin Microbiol 2020;58:e00776-20.

48. Wyllie AL, Fournier J, Casanovas-Massana A, et al. Saliva is more sensitive fo SARS-CoV-2 detection in COVID-19 patients than nasopharyngeal swabs. medRxiv 2020 Apr. 22. doi: 10.1101/2020.04.16.20067835.

49. Pasomsub E, Watcharananan SP, Boonyawat K, et al. Saliva sample as a non-invasive specimen for the diagnosis of coronavirus disease 2019: a cross-sectional study. Clin Microbiol Infect 2020 May 15 [Epub ahead of print]. doi: 10.1016/j.cmi.2020.05.001.

50. Jamal AJ, Mozafarilhashjin M, Coomes E, et al.; Toronto Invasive Bacterial Diseases Network COVID-19 Investigators. Sensitivity of nasopharyngeal swabs and saliva for the detection of severe acute respiratory syndrome coronavirus 2. Clin Infect Dis 2020 June 15 [Epub ahead of print]. doi: 10.1093/cid/ciaa848.

51. Rodino KG, Espy MJ, Buckwalter SP, et al. Evaluation of saline, phosphate buffered saline and minimum essential medium as potential alternatives to vira transport media for SARS-CoV-2 testing. J Clin Microbiol 2020;58:e00590-20.

52. Fomsgaard AS, Rosenstierne MW. An alternative workflow for molecular detection of SARS-CoV-2 - escape from the NA extraction kit-shortage, Copenhagen, Denmark, March 2020. Euro Surveill 2020;25:2000398.

53. Alcoba-Florez J, González-Montelongo R, Íñigo-Campos A, et al. Fast SARS-CoV-2 detection by RT-qPCR in preheated nasopharyngeal swab samples. Int J Infect Dis 2020;97:66-8.

54. Smyrlaki I, Ekman M, Lentini A, et al. Massive and rapid COVID-19 testing is feasible by extraction-free SARS-CoV-2 RT-qPCR. medRxiv 2020 Aug. 5. doi: 10.1101/2020.04.17.20067348.

55. Abdalhamid B, Bilder CR, McCutchen EL, et al. Assessment of specimen pooling to conserve SARS CoV-2 testing resources. Am J Clin Pathol 2020;153:715-8.

56. Lohse S, Pfuhl T, Berkó-Göttel B, et al. Pooling of samples for testing for SARSCoV-2 in asymptomatic people. Lancet Infect Dis 2020 Apr. 28 [Epub ahead of print]. doi: 10.1016/S1473-3099(20)30362-5. 
57. Siddarth D, Weyl EG. Why we must test millions a day. COVID-19 Rapid Response Impact Initiative, White Paper 6. Cambrdige (MA): Edmond J. Safra, Center for Ethics; 2020.

58. Allen D, O'Connor E, Berry S, et al. National COVID-19 Testing Action Plan: pragmatic steps to reopen our workplaces and our communities. New York: Rockefeller Foundation; 2020. Available: www.rockefellerfoundation.org/national-covid-19 -testing-action-plan/ (accessed 2020 Apr. 30).

59. Black JRM, Bailey C, Przewrocka J, et al. COVID-19: the case for health-care worker screening to prevent hospital transmission. Lancet 2020;395:1418-20.

60. Tacklling COVID-19: health, quarantine and economic measures - Korean experience [press release]. The Government of the Republic of Korea; 2020. Available: http://english.moef.go.kr/pc/selectTbPressCenterDtl.do?boardCd=N0001\&seq= 4868 (accessed 2020 May 14).

61. Gibney E. Whose coronavirus strategy worked best? Scientists hunt most effective policies. Nature 2020;581:15-6.

62. German coronavirus testing capacity increases to 900,000 a week. Stockholm (Sweden): The Local Europe AB; 2020 Apr. 29. Available: www.thelocal. de/20200429/german-coronavirus-testing-capacity-increases-to-900000-a-week (accessed 2020 May 14).

63. Tromberg BJ, Schwetz TA, Pérez-Stable EJ, et al. Rapid scaling up of COVID-19 diagnostic testing in the United States: the NIH RADx Initiative. N Engl J Med 2020 July 22 [Epub ahead of print]. doi: 10.1056/NEJMsr2022263.

64. Lisboa Bastos M, Tavaziva G, Abidi SK, et al. Diagnostic accuracy of serological tests for covid-19: systematic review and meta-analysis. BMJ 2020;370:m2516.

65. COVID-19 Immunity Task Force: helping to guide Canada's epidemic response [main page]. Available: www.covid19immunitytaskforce.ca/ (accessed 2020 Aug. 14).

66. Rasmussen S, Sperling P, Poulsen MS, et al. Medical students for health-care staff shortages during the COVID-19 pandemic. Lancet 2020;395:e79-80.
67. Miller DG, Pierson L, Doernberg S. The role of medical students during the COVID-19 pandemic. Ann Intern Med 2020;173:145-6.

68. Kives B. Manitoba boosts COVID-19 testing capacity - but still falls shy of mark set by premier. CBC News 2020 July 24. Available: www.cbc.ca/news/canada/manitoba/ manitoba-cadham-dynacare-covid-testing-1.5661784 (accessed 2020 Aug. 14).

69. Kwon KT, Ko JH, Shin H, et al. Drive-through screening center for COVID-19: a safe and efficient screening system against massive community outbreak. $J$ Korean Med Sci 2020;35:e123.

70. Lee VJ, Chiew CJ, Khong WX. Interrupting transmission of COVID-19: lessons from containment efforts in Singapore. J Travel Med 2020;27:taaa039.

71. Hsu LY, Chia PY, Vasoo S. A midpoint perspective on the COVID-19 pandemic. Singapore Med J 2020;61:381-3.

72. Seedat J, Paape C. Impfstatus der Kinder und Jugendlichen in Deutschland, STIKO: Influenzaimpfungen in der COVID-19-Pandemie. Epidemiologisches Bulletin. Berlin (Germany): Robert Koch-Institut; 2020.

73. ALM - Akkreditierte Labore in der Medizin e. V. [main page]. Available: www. alm-ev.de/startseite.html (accessed 2020 May 15).

74. Uppal A, Campbell JR, Oxlade O, et al. An interactive Excel file to estimate costs of expanded testing for COVID-19 by RT-PCR and/or serologic tests. Version 2.0. Geneva: CERN, European Organization for Nuclear Research; 2020. Available: https://zenodo.org/record/3964991 (accessed 2020 July 28).

75. Hellewell J, Abbott S, Gimma A, et al. Feasibility of controlling COVID-19 outbreaks by isolation of cases and contacts. Lancet Glob Health 2020;8:e488-96.

76. Giordano G, Blanchini F, Bruno R, et al. Modelling the COVID-19 epidemic and implementation of population-wide interventions in Italy. Nat Med 2020;26:855-60.

77. Ali ST, Wang L, Lau EHY, et al. Serial interval of SARS-CoV-2 was shortened over time by nonpharmaceutical interventions. Science 2020 July 21 [Epub ahead of print]. doi: 10.1126/science.abc9004.
Competing interests: Alton Russell has provided consulting services to Terumo BCT, a medical device company, unrelated to and outside the submitted work; Terumo BCT does not manufacture diagnostic tests. Stephanie Law is a part-time employee at Carebook Technologies Inc., a mobile app tech company; Carebook Technologies Inc. is currently pilottesting an app for monitoring symptoms related to coronavirus disease 2019 (COVID-19); this is unrelated to and outside the submitted work. Jonathon Campbell reports that he has received consulting fees from the COVID-19 Immunity Task Force, outside and unrelated to the submitted work. The fees were received and the work performed after initial submission of the present manuscript. Olivia Oxlade reports being Associate Scientific Director (Management) for the COVID-19 Immunity Task Force. All of the work related to this manuscript was done while Dr. Oxlade was part of the McGill International TB Centre and before this position started. Timothy Evans is Executive Director of the COVID19 Immunity Task Force. No other competing interests were declared.

This article has been peer reviewed.

Affiliations: Research Institute of the McGill University Health Centre (Campbell, Oxlade, Fregonese, Menzies, Oh, Bastos, Sulis); Faculty of Medicine (Campbell, Menzies, Winters, Sulis, Uppal, Yanes-Lane, Lan), McGill University; McGill International TB Centre (Campbell, Oxlade, Fregonese, Menzies, Bastos, Sulis, Law); Department of Economics (Laszlo) and School of Population and Global Health (Evans), McGill University, Montréal, Que.; Department of Management Science and Engineering (Russell), Stanford University, Stanford, Calif.; Department of Pediatrics (Oh), Kosin University College of Medicine, Busan, Republic of Korea; Department of Epidemiology (Bastos), Social Medicine Institute, State University of Rio de Janeiro, Rio de Janeiro, Brazil; Department of Global Health and Social Medicine (Law), Harvard Medical School, Boston, Mass.; Département de médicine social et preventive (Brisson), Université Laval, Québec, Que.

Contributors: Dick Menzies, Jonathon Campbell, Alton Russell, Timothy Evans and Olivia Oxlade contributed to the conception and design of the work. All of the authors contributed to the acquisition and interpretation of data. Jonathon Campbell, Aashna Uppal, Dick Menzies analyzed the data. Jonathon Campbell and Dick Menzies drafted the manuscript. All of the authors revised it critically for important intellectual content, gave final approval of the version to be published and agreed to be accountable for all aspects of the work.

Funding: This study is directly funded by an operating grant (ECRFR1-30) from the McGill Interdisciplinary Initiative in Infection and Immunity (MI4), a philanthropic scientific-granting organization with peerreviewed competition; Dick Menzies was the Principal Investigator and Jonathon Campbell the co-Principal Investigator. The grant also supports the salaries of Aashna Uppal and Mercedes Yanes-Lane. Jonathon Campbell (Award \#258907, Award \#287869) and Stephanie Law (Award \#258467) are funded by a postdoctoral fellowship from the Fonds de Recherche du Québec-Santé. Nicholas Winters (Award \#284837) is funded by a doctoral fellowship from the Fonds de Recherche du Québec - Santé. W. Alton Russell is funded by a Stanford Interdisciplinary Graduate Fellowship. Mayara Bastos, Federica Fregonese, Nicholas Winters, Jonathon Campbell and Olivia Oxlade are funded through a Canadian Institutes of Health Research grant (\#FRD143350). Giorgia Sulis is funded by a Richard H. Tomlinson Doctoral Fellowship.

Role of the funder: All funders had no role in the design and conduct of the study; collection, management, analysis and interpretation of the data; preparation, review, or approval of the manuscript; and decision to submit the manuscript for publication.

Data sharing: All data used to inform this manuscript are available in the main text, supplemental material, and online within our Excel tool (https://zenodo.org/record/3964991).

Acknowledgements: The authors thank Dr. Andrea Benedetti for statistical advice on surveillance testing, Ms. Danielle Sampath for administrative and technical support, Dr. Marcel Behr and Dr. Cedric Yansouni for advice on laboratory aspects, Dr. Kevin Schwartzman and Dr. Raymond Tellier for a critical review of an earlier version of this work, and Dr. Noémie Savard and all other Quebec health officials who provided important contextual information informing the development and resource needs for the strategies analyzed.

Accepted: Aug. 24, 2020

Correspondence to: Dick Menzies, dick.menzies@mcgill.ca 